\title{
A PANDEMIA DO COVID-19 E O ACESSO AOS DIREITOS E À JUSTIÇA - REFLEXÓES SOBRE SEUS EFEITOS NO PRESENTE E NO FUTURO DA ATUAÇÃO DA DEFENSORIA PÚBLICA
}

\author{
THE COVID-19 PANDEMIC AND ACCESS TO RIGHTS AND JUSTICE - REFLECTIONS ON ITS \\ EFFECTS ON THE PRESENT AND FUTURE OF PUBLIC DEFENDER'S PERFORMANCE
}

Cleber Francisco Alves

Doutor em Direito pela PUC-Rio, com estágio Pós-Doutoral na Universidade de Londres. Professor Associado da Universidade Federal Fluminense (UFF). Professor Titular da Faculdade de Direito da Universidade Católica de Petrópolis (UCP). Defensor Público no Estado do Rio de Janeiro, titular da

24a Câmara Civel no TJ-RJ.

\section{INTRODUÇÃO}

No final do ano de 2019 o mundo foi surpreendido com a descoberta de um novo tipo de vírus, que teria sido identificado pela primeira vez na cidade de Wuhan, na China. Esse vírus, variante da família conhecida como "coronavírus", foi oficialmente denominado, no meio científico, de SARs-CoV-2. Ele foi identificado como causador de uma espécie grave de pneumonia - depois designada de "síndrome respiratória aguda grave", ou simplesmente, COVID-19. E transmitido através de gotículas expelidas do nariz ou da boca da pessoa infectada, causando sintomas que podem variar entre febre, cansaço, perda do paladar e olfato resultando em alguns casos mais graves num quadro de insuficiência respiratória aguda que se revela fatal principalmente em pacientes mais idosos. Porém, muitas pessoas que contraem o vírus permanecem assintomáticas o que acaba dificultando o registro e controle da disseminação da doença.

Em março de 2020, após uma rápida expansão do contágio da doença pelo mundo afora, a OMS - Organizaçáo Mundial da Saúde declarou formalmente que estava configurada a situação de pandemia. A capacidade de propagação do vírus e a gravidade da doença são notórias tendo em vista que - apesar de todas as medidas e esforços no sentido de conter sua disseminação e minimizar seus efeitos - até o final de janeiro de 2021 já haviam sido registrados mais de 100 milhóes de casos no mundo, ultrapassada a casa de 2 milhóes e 200 mil pessoas mortas em razão da doença ${ }^{1}$. No Brasil as estatísticas revelam números lamentáveis, com um percentual total de contágios e, sobretudo, de mortes muito superiores à média mundial: com apenas $2,8 \%$ da população global, o Brasil terminou o ano de 2020 com 10,8\% das mortes provocadas pela COVID-19 em todo o mundo. O país tinha, em 31/12/2020, mais de $9 \%$ do total de pessoas infectadas pelo novo coronavírus: dos cerca de 83 milhóes de casos de COVID-19 registrados no mundo em 2020, o Brasil

\footnotetext{
1 Informaçóes obtidas na plataforma Our World in Data, ou "Nosso Mundo em Dados", em tradução livre. Tal plataforma foi criada a partir de um esforço coletivo de pesquisadores da Universidade de Oxford e da organização sem fins lucrativos Global Change Data Lab. Os dados coletados sáo usados por grandes jornais, como The New York Times, BBC, Guardian e The Washington Post, além de outras publicaçóes, como a Science e Nature. Ver: https://ourworldindata.org/coronavirus. Acesso em 01/02/2021.
} 
respondeu por 7.675.973. E certamente esses números devem ser ainda maiores, em razão de ocorrência de subnotificação.

A eclosão da pandemia do COVID-19, formalmente declarada no início do ano 2020, provocou impactos dramáticos e profundos na vida cotidiana da maioria dos habitantes do planeta. Em todas as atividades humanas foram sentidos os efeitos dessa terrível e insidiosa doença para cujo enfrentamento, paradoxalmente, apesar do sofisticado estágio de desenvolvimento científico e tecnológico contemporâneo, pouquíssimas naçóes estavam preparadas. Os sistemas de saúde de muitos países colapsaram. As atividades econômicas sofreram duros revezes, em razão da necessidade de observar as determinaçóes de autoridades sanitárias impondo medidas de afastamento social e, em alguns casos mais drásticos, de total lock down. Tais medidas afetaram principalmente os setores do comércio, dos serviços - notadamente o turismo, atividades culturais e de lazer - e, também, da indústria. O sistema educacional teve que se reconfigurar, com fechamento das escolas, passando o ensino a ser ministrado de forma remota aos estudantes em seu próprio domicílio ${ }^{2}$, com utilização de recursos tecnológicos através de plataformas digitais, com acesso pela internet.

Esse quadro de desafios e transformaçóes não foi diferente no âmbito dos sistemas de acesso à justiça. A necessidade de distanciamento e, até mesmo, de total isolamento social implicou na interrupção das atividades predominantemente presenciais dos serviços forenses e de assistência jurídica e impôs a adoção de novas rotinas e procedimentos destinados a assegurar a continuidade da prestaçáo desses serviços, considerados essenciais para a preservação da ordem e da paz social. Os órgãos judiciais e os profissionais que atuam nas diversas funçóes jurídicas passaram a atuar em regime de atendimento remoto, totalmente dependentes do uso de equipamentos e recursos tecnológicos para o processamento de dados e para viabilizar a comunicação e interação entre os prestadores dos serviços e os respectivos destinatários.

Tendo presente essa conjuntura, o presente artigo tem o objetivo de trazer informaçóes sobre os impactos da pandemia do COVID-19 no que se refere especificamente ao acesso aos direitos e à justiça, numa visão panorâmica da realidade nacional e internacional.

O primeiro capítulo propóe uma reflexão em que se situa a eclosão da pandemia no contexto mundial, de transição de um modelo de organização política ainda marcado pelo dogma da soberania territorial dos Estados Nacionais mas que se coloca numa transição para um novo cenário de configuração transnacional. Diante desse cenário marcado por desafios, aporias e incertezas, se procurará analisar - de modo crítico - as estratégias adotadas pelos diversos países no enfrentamento da pandemia do COVID-19.

\footnotetext{
2 Para uma reflexão mais aprofundada sobre os impactos da pandemia do COVID-19 no sistema educacional sugere-se consulta a: KLOH, Fabiana Ferreira Pimentel; ALVES, Cleber Francisco. Conselho Tutelar diz que aulas presenciais violam direitos das crianças: o relativismo na obrigatoriedade da frequência à escola e a opção pela educação domiciliar. In: VASCONCELOS, Maria Celi Chaves (org). Educaçáo Domiciliar no Brasil: mo(vi)mento em debate. Curitiba: Editora CRV, 2021. pp. 95-113. Ver também, no mesmo livro, o capítulo "Reflexóes acerca da Educação Domiciliar e da Desescolarizaçáo a partir do cenário de pandemia", de autoria de Aline Lyra e Antônio Jorge Gonçalves Soares.
} 
No segundo capítulo o estudo se voltará de modo mais específico para uma análise dos impactos da COVID-19 no âmbito dos sistemas de justiça e dos serviços de assistência jurídica gratuita, numa perspectiva mundial e nacional.

No terceiro e último capítulo nossa proposta é a de trazer consideraçóes e reflexões sobre os efeitos da pandemia no presente e no futuro da atuaçáo da Defensoria Pública, tendo em vista principalmente os desafios e potencialidades decorrentes da necessidade de transformação radical do modo de prestação de seus serviços, durante esse período de compulsório isolamento social. Também discorreremos sobre as prováveis dificuldades que serão enfrentadas para cumprimento da meta estabelecida na EC 80/2014, de plena cobertura territorial da presença da Defensoria Pública em todos as unidades federativas do Brasil.

Encerrando o trabalho, apresentaremos algumas consideraçóes finais, destacando que a pandemia do COVID-19 evidenciou a importância do fortalecimento e aprimoramento de serviços públicos estatais como o prestado pela Defensoria Pública brasileira.

\section{A ECLOSÃO DA PANDEMIA DO COVID-19 NO CENÁRIO DE UM MUN- DO “TRANSNACIONAL” E AS ESTRATÉGIAS DE ENFRENTAMENTO NOS DIVERSOS PAÍSES}

$\mathrm{Na}$ história da humanidade ${ }^{3}$, são recorrentes os registros de surtos pandêmicos que provocaram efeitos devastadores de grande magnitude. A pior delas teria sido a "Peste Negra", no Século XIV, que dizimou boa parte da população da Europa, e também da Ásia. Não há dados precisos registrados historicamente, mas estima-se que o número de mortos tenha sido de 75 milhóes a 200 milhóes de pessoas, o que se deu ao longo de um período de cerca de 7 anos (1346-1353). Há cerca de 100 anos, no início do Século XX, entre os anos de 1918 e 1920, a chamada "Gripe Espanhola" parece ter sido a primeira pandemia de alcance efetivamente mundial, afetando países de todos os continentes. Calcula-se que cerca de $25 \%$ da população mundial foi atingida, sendo o número de mortos estimado entre 20 e 40 milhóes de pessoas. As precárias condiçôes de higiene, o elevado nível de pobreza e o ainda incipiente estágio do conhecimento técnico-científico na área de saúde pública explicam esse número tão alto de vítimas fatais.

Considerando-se o vertiginoso progresso alcançado pelas ciências e pela medicina ao longo do século XX, e a sofisticação dos recursos tecnológicos para processamento de dados e comunicação, potencializados ainda mais nestes tempos de ampla expansão da internet, podia-se supor que seria improvável a eclosão de novos surtos pandêmicos, em pleno Século XXI, de grandes proporçôes quanto à letalidade e alcance territorial. Porém, a rápida e devastadora propagaçáo da pandemia do COVID-19 contrariou todos esses prognósticos. Essa propagação foi amplamente favorecida pela realidade contemporânea de um mundo globalizado, com uma população mundial na casa dos 7 bilhóes de pessoas, cuja circulação

3 Para uma visão panorâmica sobre o histórico das pandemias, ver: UJVARI, Stefan Cunha. Pandemias: a humanidade em risco. São Paulo: Contexto, 2011. 
entre os países é facilitada ${ }^{4}$ por um sistema de transporte aéreo com notável estágio de conectividade e eficiência, que torna possível atravessar o planeta no espaço de apenas um dia.

Por mais paradoxal que pareça, embora o mundo contemporâneo tenha se tornado uma espécie de "aldeia global", em que as pessoas tem a facilidade de transporte internacional relativamente barato e seguro, de comunicação imediata via internet, com acompanhamento em tempo real dos fatos e acontecimentos que se passam nos mais longínquos recantos do planeta, muitos são os obstáculos e dificuldades que se póem para superação de certos problemas e a resolução de graves questóes que ainda assolam a humanidade. $\mathrm{O}$ modelo de organizaçáo política vigente na comunidade internacional, baseado no dogma da soberania territorial dos Estados Nacionais ${ }^{5}$, parece que - em muitos aspectos - náo mais se compatibiliza com as necessidades e desafios da realidade contemporânea, que assume cada vez mais uma dimensão transnacional. Esse cenário atual caracteriza-se "por uma complexa teia de relaçóes políticas, sociais, econômicas e jurídicas, que, consequentemente faz emergir novos atores, interesses e

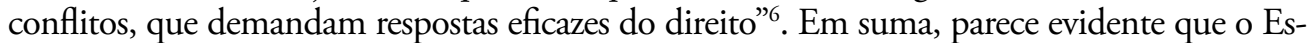
tado Nacional não é mais capaz de dar respostas adequadas às complexas e difusas demandas de cunho transnacional que se fazem presentes no mundo contemporâneo ${ }^{7}$.

Exatamente nesse cenário de crise do modelo dos Estados Nacionais, em que a realidade da globalização torna cada vez mais notória a necessidade de compreensão e análise dos problemas a partir de um novo paradigma, que tem sido designado de "transnacionalidade" ${ }^{8}$, marcado pela preocupação com a efetividade de direitos difusos e transfronteiri$\operatorname{ços}^{9}$, que deve ser situada a eclosão e propagaçáo da pandemia do COVID-19. O modo errático com que muitos países estáo lidando com a pandemia e as dificuldades que as organizaçóes internacionais, como a OMS, tem enfrentado para desempenhar sua missão ${ }^{10}$ deixam patente as características de índole transnacional do problema, cuja solução não será alcançada de modo eficaz se conduzida sob a perspectiva do paradigma do nacionalismo, e cujos impactos sociais, ambientais e econômicos vão se fazer sentir, em escala mundial, ainda por muito tempo.

\footnotetext{
4 Segundo dados da IATA, no ano de 2018, antes da pandemia, as companhias aéreas transportaram 4,4 bilhóes de passageiros ao redor do mundo. Dados disponíveis em: https://www.iata.org/contentassets/f8 d2fbbfe2664612a1e4e65a22422dc3/2019-07-31-01-sp.pdf. Acesso em 09/02/2021.

5 CRUZ, Paulo Márcio. Da Soberania à Transnacionalidade: Democracia, Direito e Estado no Século XXI. Itajaí: UNIVALI, 2014.

${ }^{6}$ CRUZ, Paulo Márcio; BODNAR, Zenildo. Globalizaçáo, Transnacionalidade e Sustentabilidade. Itajai: UNIVALI, 2012, p. 41.

7 Esse impasse está bem ressaltado por Jurgen Habermas, na sua obra "Màs allá del Estado Nacional". Traducción y introducción de Manuel Jiménez Redondo. 4ed. Madrid: Trota, 2008.

8 GARCIA, Marcos Leite. Direitos Fundamentais e Transnacionalidade: um estudo preliminar. In: CRUZ, Paulo Márcio; STELZER, Joana (orgs.). Direito e Transnacioinalidade. Curitiba: Juruá, 2009, pp. 174-181.

9 Nessa categoria estão abrangidas, por exemplo, as questōes relativas ao meio ambiente, sustentabilidade, solidariedade, direitos humanos e equidade étnico-racial, sistemas de comunicação e de circulação de informações e dados, etc.

${ }^{10}$ Em grande medida essas dificuldades decorrem da falta de caráter coercitivo para suas determinaçóes, que juridicamente são compreendidas como meras "recomendaçóes", muitas vezes desprezadas e até questionadas sem qualquer embasamento técnico-científico.
} 
Feitas essas consideraçôes e reflexóes situando a eclosão da pandemia do COVID-19 no cenário contemporâneo de um mundo transnacional, faremos uma breve digressão crítica sobre as estratégias que tem sido adotadas pelos Estados Nacionais para o enfrentamento da doença e de suas consequências na esfera doméstica de cada país. Inúmeros tem sido os estudos publicados relatando medidas adotadas, analisando sua eficácia e comparando os resultados obtidos. Segundo tais estudos vários são os fatores que podem ser relevantes para se compreender as alternativas disponíveis e opçóes ou estratégias escolhidas em cada caso. Para maior aprofundamento, vale a pena consultar a obra publicada pela Editora da Universidade de Michigan (EUA), que tem dentre as organizadoras a professora brasileira Elize Massard da Fonseca. ${ }^{11}$

Logo após identificar o surgimento do vírus SARS-Cov-2, e sua rápida propagação causadora da COVID-19, a China adotou medidas drásticas e incisivas de isolamento de mais de 50 milhóes de pessoas habitantes na Província de Wuhan onde o novo coronavírus teria pela primeira vez infectado seres humanos. Paralelamente, foram adotadas medidas de monitoramento e rastreamento rigoroso de casos confirmados da doença, com imposição de isolamento total de todos os que tivessem tido contato com pessoas infectadas. A obrigatoriedade do uso de máscaras e medidas de distanciamento social também foram sistematicamente adotadas. Considerando o gigantismo da China (em termos territoriais e populacionais), há que se reconhecer o êxito alcançado: até janeiro de 2021 o número total de casos no país era de pouco mais de 87.000 , sendo 4.634 mortos, o que representa um percentual de pouco mais de 3 mortes por milhão de habitantes ${ }^{12}$.

Vários países asiáticos seguiram mais ou menos esse mesmo padrão de medidas para evitar a propagação da doença, o que resultou no baixíssimo número de casos. Por exemplo, no Vietnã, até dezembro de 2020, haviam sido registrados apenas 35 mortes e 1385 casos, numa população de cerca de 97 milhóes de habitantes ${ }^{13}$. O índice de mortes por milhão de habitantes era de menos de maior por cento (mais precisamente, 0.36). Em Taiwan, esse índice era ainda menor (0.34): até janeiro de 2021 eram apenas 7 mortes, dentre 843 casos, dos quais 746 de pessoas que contraíram o vírus fora do país, isso numa população de quase 24 milhóes de habitantes. Fora da Ásia, o caso mais bem sucedido parece ter sido o da Nova Zelândia ${ }^{14}$.

11 GREER, Scott L.; KING, Elizabeth J.; PERALTA-SANTOS, André; FONSCA, Elize Massard (ed.). Coronavirus Politics - The Comparative Politics and Policy of COVID-19. Michigan: University of Michigan Press, 2021.

12 Esse número configura-se baixíssimo se comparado com outros países de grande extensão territorial: o índice dos EUA, em 31/01/2021, era de mais de 1500 mortos por milháo de habitantes, e o da União Europeia era de mais de 1200, conforme dados obtidos na plataforma Our World in Data, ou "Nosso Mundo em Dados”, em tradução livre. Ver: https://ourworldindata.org/coronavirus. Acesso em 31/01/2021.

13 Ver: https://jornal.usp.br/radio-usp/apos-sobreviver-a-china-e-eua-vietna-vem-superando-tambem-apandemia/. Acesso em 31/01/2021.

${ }_{14}$ De acordo com estudo realizado pelo think-tank australiano Lowy Institute, divulgada em janeiro de 2021 a Nova Zelândia teria sido o país com melhor gestão da pandemia do COVID-19, num universo de quase 100 naçóes estudadas. Com 5 milhóes de habitantes, o país havia contabilizado menos de 2 mil casos e apenas 25 mortes no final de janeiro de 2021.Ver: https://interactives.lowyinstitute.org/features/covid-performance/. Acesso em 31/01//2021. 
Os países da Europa, notadamente a Itália, a Espanha e o Reino Unido, que de início relutaram em tomar medidas mais drásticas para a contenção da doença, foram surpreendidos com a vertiginosa propagação do novo coronavírus nos primeiros meses de 2020, que provocou o colapso de seus sistemas de saúde, com um altíssimo índice de letalidade. Diante do caótico quadro verificado, foram necessárias medidas drásticas de lockdown, com fechamento de escolas, igrejas, interrupção do tráfego aéreo e fechamento das fronteiras à entrada de estrangeiros. Foram também adotadas medidas de proteção social, com suporte financeiro às empresas para manutenção de empregos e fomentos às atividades econômicas mais afetadas pelas medidas de lockdown.

Os Estados Unidos demoraram muito a adotar políticas públicas e medidas destinadas a conter a propagação da COVID-19, em razáo da postura ostensivamente "negacionista", do então Presidente Donald Trump. Em grande medida, certamente como decorrência desse tipo de conduta errática, a pandemia se alastrou pelo país, provocando situação caótica nos sistemas de saúde de muitas cidades e um número alarmante de mortos.

No cenário mundial, de certo modo, parece surpreendente o número relativamente baixo de casos e letalidades verificados no continente africano. Temia-se que, devido ao elevado índice de pobreza e fragilidades no sistema de saúde e acesso a medicamentos, ocorreria uma severa disseminação da doença na África. De acordo com dados da Organização Municipal de Saúde, na Região Africana tinham sido registrados apenas 2.703 .899 casos até 12/02/2021, sendo um total de 67.586 mortes. Esse número contrasta de modo gritante com aqueles da América Latina, que teria cerca de 20 milhóes de casos e mais de 600 mil mortes nessa mesma data ${ }^{15}$.

Para uma visão panorâmica acerca das medidas e estratégias concretas adotadas pelos mais variados países no enfrentamento da pandemia do COVID-19, tomaremos como base dados coletados em pesquisa realizada no âmbito do Global Access to Justice Project, em cooperaçáo com a Universidade Federal Fluminense (UFF) ${ }^{16}$, de que participaram representantes de cerca de 50 países. De acordo com dados obtidos nessa pesquisa, 86\% desses países adotaram restriçóes em relação às viagens internacionais, seja proibindo a entrada de estrangeiros (39\%), seja impedindo o ingresso de viajantes advindos de determinados países (27\%), ou mesmo vedando a entrada de toda e qualquer pessoa, incluindo cidadãos e residentes que desejem retornar ao país $(20 \%)$.

A referida pesquisa revelou ainda a maciça adoção pelos governos nacionais ( $86 \%)$ de medidas assistenciais em prol das populaçôes necessitadas. Dentre tais medidas, destaca-se: (i) a concessão de auxílios financeiros diretos e subsídios mensais a pessoas que ficaram desempregadas ou cuja renda tenha sido afetada em decorrência da pandemia (Brasil, Camboja, Chile, Colômbia, Cuba, Chipre, Espanha, Finlândia, Índia, Japão, Quênia, Nova Zelândia, Macedônia do Norte, Paquistão e Taiwan); (ii) a isenção de tributos para pessoas físicas (Cuba e Mongólia); (iii) a isenção de cobrança por serviços públicos essen-

\footnotetext{
15 Dados disponíveis em: https://covid19.who.int/ Acesso em 12/02/2021.

16 Para mais informações sobre o Global Access to Justice Project e, especificamente sobre essa pesquisa aqui mencionada, ver: http:/globalaccesstojustice.com/impacts-of-covid-19/?lang=pt-br. Acesso em 12/02/2021.
} 
ciais como gás, eletricidade e taxas de limpeza (Geórgia e Nepal); (iv) a prorrogação ou desoneração de obrigaçóes tributárias para empresas e microempresas (Brasil, Colômbia, Finlândia, Seychelles, Espanha e Taiwan); (v) a suspensão da prestação de garantias fiscais (Chipre); (vi) a concessão de auxílio-doença a trabalhadores infectados (Chipre); (vii) a facilitação do acesso a benefícios sociais como o auxílio-desemprego (Nova Zelândia e Espanha); (viii) a concessão de licença paternidade especial de até quatro semanas para cidadãos com filhos (Chipre); (ix) a suspensão das operaçóes comerciais por parte de empresas e microempresas, permanecendo o não recolhimento fiscal condicionado a não demissão de funcionários durante a pandemia (Chipre); (x) a distribuição de alimentaçáo in natura ou cupons para aquisição de alimentos (Brasil, Etiópia, Índia, Quênia, Paquistão e Estados Unidos); (xi) o diferimento no pagamento de encargos contratuais diversos como taxas, juros, multas e empréstimos. Detectou-se também que a pandemia afetou severamente a rotina de estudos em todo o planeta, sendo identificado o fechamento compulsório de instituiçóes de ensino em $94 \%$ dos países analisados ${ }^{17}$.

No caso do Brasil, muitas das medidas adotadas em outros países do mundo também foram aqui implementadas. Logo no início do ano de 2020, quando já se vislumbrava um horizonte preocupante quanto à disseminação internacional da COVID-19, foi aprovada a Lei Federal no $13.979^{18}$, de 6 de fevereiro de 2020, onde foram previstas medidas passíveis de serem adotadas pelas autoridades públicas para o enfrentamento da situação de emergência em saúde pública ${ }^{19}$ decorrente do surto do novo coronavírus. Dentre essas medidas elencadas no Art. $3^{\circ} \mathrm{da}$ referida Lei, podemos mencionar: isolamento, quarentena, determinação compulsória de exames médicos, coleta de amostras clínicas, vacinação e outra medidas profiláticas, uso obrigatório de máscaras de proteção individual, restrição excepcional e temporária de entrada e saída do país, de locomoçáo interestadual e intermunicipal. Por se tratar o Brasil de um país de dimensão continental, com características regionais e locais muito variadas, e em que vigora o regime de governo federativo, surgiram muitas controvérsias quando à efetivação, na prática, de várias dessas medidas, quando da eclosão da pandemia, a partir de março de 2020. A Constituição Federal brasileira de 1988 adotou um modelo que costuma ser designado de "federalismo cooperativo" no qual a União, os Estados e Municípios compartilham competências e responsabilidades quanto à edição de normas jurídicas e à prestação dos serviços públicos, observado o princípio da predominância de interesses. Desse modelo deveria resultar um papel de protagonismo da Uniáo no que se refere ao planejamento, coordenação e diretrizes de âmbito nacional para o enfrentamento da pandemia, cabendo aos Estados e Municípios, conforme o caso, adequar e aplicar essas diretrizes no seu âmbito territorial, sempre com o intuito de assegurar maior eficácia possível para a proteção da saúde dos cidadãos. Porém,

${ }_{17}$ ESTEVES, Diogo; ALVES, Cleber Francisco; SILVA, Franklyn Roger Alves; Azevedo, Júlio Camargo. Acesso à Justiça em tempos de pandemia: o impacto global do COVID-19 nas instituiçóes político-jurídicas. Confluências - Revista Interdisciplinar de Sociologia e Direito. Niterói-RJ, Vol. 22, N. 2, ago/dez 2020, pp. 147-170.

18 Ao longo do ano de 2020, outras normas legais foram aprovadas, introduzindo modificaçōes ou acréscimos nas regras estabelecidas por essa Lei. Foi o caso das Leis no 14.006, 14.019 e 14.039, todas de 2020.

${ }_{19} \mathrm{Na}$ data da promulgação dessa Lei, a Organização Municipal de Saúde ainda não havia declarado formalmente o estágio de pandemia, mas de "situação de emergência internacional". 
não foi exatamente isso o que ocorreu ${ }^{20}$, o que acabou levando muitas controvérsias para serem dirimidas na esfera judicial, suscitando dúvidas e embates que tem dificultado sobremaneira a eficácia do combate à disseminaçáo da doença no Brasil.

O fato é que, lamentavelmente, fatores de cunho ideológico e político ${ }^{21}$ acabaram interferindo fortemente na definição dos rumos, estratégias e prioridades das políticas públicas relacionadas ao enfrentamento da pandemia no Brasil, o que resultou no profundo agravamento e amplificação do quadro crítico decorrente da pandemia do COVID-19 em nosso país. Segundo estudo internacional já antes mencionado, feito por conceituado Instituto de Pesquisas da Austrália - o Lowy Institute, divulgada em janeiro de 2021, o Brasil foi considerado o pais que teve a pior gestão de políticas públicas, num universo de 100 naçóes estudadas ${ }^{22}$. Essa percepção está em sintonia com dados sistematizados na pesquisa "Mapeamento e análise das normas jurídicas de resposta à COVID-19 no Brasil”, realizada pelo Centro de Pesquisas e Estudos de Direito Sanitário (CEPEDISA) da Faculdade de Saúde Pública da Universidade de São Paulo (USP), em parceria com a ONG - Conectas Direitos Humanos ${ }^{23}$. De acordo com as pesquisadoras Deisy Ventura e Rossana Reis, da USP, náo teria ocorrido propriamente "incompetência e negligência" na gestão da pandemia mas sim uma "estratégia institucional de propagação do vírus, promovida pelo governo brasileiro sob a liderança da Presidência da República”, cujo objetivo seria a retomada da atividade econômica o mais rápido possível e a qualquer

\footnotetext{
${ }^{20}$ Ver: MARRAFON, Marco Aurélio. CF estabelece cooperação federativa para superar crise do coronavírus. In: ConJur - Revista Eletrônica Consultor Jurídico. Disponível em: https://www.conjur. com.br/2020-mar-30/constituicao-poder-cf-estabelece-cooperacao-federativa-crise-covid-19. Acesso em $10 / 02 / 2021$.

${ }^{21} \mathrm{Na}$ mesma linha da postura adotada pelo Presidente dos Estados Unidos da América, o Chefe de Governo do Brasil, Presidente Jair Bolsonaro assumiu uma postura negacionista acerca dos critérios técnicos e científicos indicados como adequados para contenção e prevenção da Covid-19, ridicularizaram o uso de máscaras, opuseram-se a medidas de isolamento social e estimularam a prevençáo e "tratamento precoce" (expressão utilizada pelo Ministro da Saúde em entrevista coletiva à imprensa, concedida no dia 21 de julho de 2020, em Porto Alegre-RS) da doença com medicamentos cuja eficácia não é reconhecida pela ciência. Para uma reflexão sobre essa questionável "estratégia" do governo brasileiro, sugere-se consulta a: https://observatoriohospitalar.fiocruz.br/conteudo-interno/estrategia-brasileira-de-combate-covid-19-comoo-vacuo-de-lideranca-minimiza-os. Acesso em 10/02/2021.

22 Ver: https://interactives.lowyinstitute.org/features/covid-performance/. Acesso em 10/02/2021.

${ }^{23}$ Trata-se de projeto que reuniu uma equipe multidisciplinar que realizou pesquisa documental para constituição de um banco de normas relacionadas à pandemia da COVID-19 no Brasil, com produção de dados para análise qualitativa de impacto potencial sobre direitos humanos, além de produção de dados para desagregação e análise quantitativa, em especial o cruzamento de dados sobre as normas com indicadores epidemiológicos. Os resultados dessa pesquisa foram divulgados em ediçóes quinzenais do BOLETIM: DIREITOS NA PANDEMIA, publicados pela Conectas Direitos Humanos. Disponível em: https://www.conectas.org/publicacoes/. Acesso em 10/02/2021).
} 
custo $^{24}$. Numa análise comparativa com as estratégias adotadas por países como a Coreia do Sul, a Alemanha e a Suécia, o pesquisador Carlos Luiz Strapazzon, da UFSC, também concluiu que "os serviços preventivos de difusão da doença não foram a prioridade na estratégia de ação do Ministério da Saúde" ${ }^{25}$ : o foco principal teria sido nas questóes de ordem econômica e não sanitária. Fomentou-se assim, segundo nos parece, um equivocado dilema e confronto entre proteção da saúde e a preservação da atividade econômica ${ }^{26}$, cujas consequências ao final e ao cabo estáo se revelando dramáticas e devastadoras tanto para a saúde dos brasileiros quanto para a economia nacional.

\section{IMPACTOS DA PANDEMIA DO COVID-19 NO ÂMBITO DO ACESSO AOS DIREITOS E À JUSTIÇA: PERSPECTIVA MUNDIAL E NACIONAL}

Após um ano do surgimento da COVID-19, é fácil constatar que poucos foram os países que estavam minimamente preparados para lidar com essa pandemia e, por esse motivo, ela tem causado terríveis impactos e transtornos na vida cotidiana. Diante do desconhecimento acerca do desenvolvimento da doença e dos contundentes efeitos por ela gerados, assim como diante da inexistência de imunizantes (vacinas) e de tratamentos médico-farmacológicos especificamente eficazes para seu tratamento, as respostas prioritárias dos governos estavam inicialmente focadas em medidas de cunho sanitário de caráter preventivo, com severas restriçóes à circulação de pessoas. Isso implicou, como já destacado, na paralisação quase completa das atividades econômicas, e fechamento de repartiçóes públicas náo consideradas como essenciais, com o intuito de retardar ou minimizar o ritmo de propagaçáo, para melhor se preparar ao seu enfrentamento, evitando assim o aumento número de vítimas fatais.

Embora as questóes principais relacionadas à pandemia do COVID-19 tenham sido relacionadas primordialmente à esfera da saúde pública, o impacto das medidas e políticas públicas adotadas para conter a disseminação do vírus tem provocado amplos e preocu-

\footnotetext{
24 Essa estratégia, segundo as referidas pesquisadoras, estaria configurada em três eixos fundamentais detalhadamente mapeados na pesquisa, consistentes em "1. atos normativos da União, incluindo a edição de normas por autoridades e órgãos federais e vetos presidenciais; 2. atos de obstrução às respostas dos governos estaduais e municipais à pandemia; e 3. propaganda contra a saúde pública, aqui definida como o discurso político que mobiliza argumentos econômicos, ideológicos e morais, além de notícias falsas e informaçóes técnicas sem comprovaçáo científica, com o propósito de desacreditar as autoridades sanitárias, enfraquecer a adesáo popular às recomendaçóes de saúde baseadas em evidências científicas, e promover o ativismo político contra as medidas de saúde pública necessárias para conter o avanço da Covid-19”. Segundo as referidas pesquisadores, houve um "empenho e a eficiência da atuação da União em prol da ampla disseminaçáo do vírus no território nacional, declaradamente com o objetivo de retomar a atividade econômica o mais rápido possível e a qualquer custo". (Ver: https://www.conectas.org/publicacoes/download/boletim-direitos-na-pandemia-no-10. Acesso em 10/02/2021.)

25 STRAPAZZON, Carlos Luiz. Respostas à pandemia e a estratégia brasileira. In: Revista Eletrônica do Centro Universitário Newton Paiva. Belo Horizonte, n. 41, mai/ago 2020, pp. 136-165.

26 Esse falso dilema já era apontado, logo no início da pandemia, por vários especialistas e pesquisadores no Brasil e no mundo. Para ilustrar os argumentos, pode-se conferir o artigo "A pandemia de Covid-19 e o isolamento social: saúde versus economia”, publicado pelos professores Andrés Ferrari e André Moreira Cunha, do Departamento de Economia da UFRGS, disponível em: https:/www.ufrgs.br/coronavirus/base/ artigo-a-pandemia-de-covid-19-e-o-isolamento-social-saude-versus-economia/ Acesso em 09/02/2021.
} 
pantes efeitos em várias outras esferas, inclusive afetando direitos humanos de diversas dimensóes, dentre os quais o direito fundamental de um acesso à justiça de modo suficientemente célere, justo, equitativo e efetivo ${ }^{27}$. Esse quadro se torna dramático quando se pensa nos grupos sociais mais vulneráveis, como é o caso de crianças e adolescentes, mulheres vítimas de violência doméstica, minorias étnicas e religiosas, migrantes, população indígena, trabalhadores informais, pessoas em situação de rua e as pessoas que vivem abaixo da linha da pobreza: todos esses são os que mais tem sofrido o impacto da pandemia. A COVID-19 tem tornado mais visíveis e eloquentes as desigualdades sociais no que se refere à distribuição da riqueza, do acesso à saúde, à educação, ao emprego, à moradia, etc. Tais desigualdades se mostram ainda mais agudas, amplificando a necessidade de mecanismos efetivos de acesso à justiça, aptos a coibir violaçóes de direitos, a solucionar conflitos, e assegurar as mínimas condiçôes de vida digna dos cidadãos mais vulneráveis no que se refere à proteção dos direitos sociais, econômicos e culturais básicos, assim reconhecidos tanto no ordenamento jurídico interno como também no plano internacional.

Conforme indicado acima, ao longo do ano de 2020, na maioria dos países do mundo foram adotadas medidas de limitação/restrição aos direitos e liberdades fundamentais, com atribuição de poderes emergenciais às autoridades públicas, consideradas necessárias para conter a propagação da doença. De acordo com pesquisa já antes mencionada, realizada no âmbito do Global Access to Justice Project, em cooperação com a Universidade Federal Fluminense (UFF) ${ }^{28}$, entre os dias 07 e 27 de abril de 2020 , em que foram coletados dados quantitativos e qualitativos de mais de 50 países, em $92 \%$ deles foram adotadas medidas de isolamento social como por exemplo: restrição à realização de reuniōes e eventos; redução da capacidade de lotação nos transportes públicos; fixação de limites de quantidade ou de duração de saídas de casa por dia e até mesmo imposição de toque de recolher. $\mathrm{Na}$ época da pesquisa, quando ainda se vivia o estágio inicial da pandemia, foi registrado que $47 \%$ dos países chegaram a impor regime de lockdown cujo descumprimento podia implicar em aplicação de penalidade pecuniária, ou seja, multa ( $73 \%$ dos países pesquisados) ou até mesmo a privação de liberdade (em $41 \%$ dos países foi mencionada a possibilidade de prisão).

$\mathrm{Na}$ maioria dos países pesquisados foram registradas medidas específicas relativas ao funcionamento do comércio e serviços, com intuito de reduzir a concentraçáo de pessoas num mesmo recinto, como por exemplo: proibição de venda de refeiçóes no interior de restaurantes e lanchonetes, sendo autorizado apenas o funcionamento na modalidade delivery (como por exemplo na Bulgária, Espanha, Itália, França); restriçãa em relação ao número de pessoas no interior dos estabelecimentos (Espanha, Itália, França e vários outros) e redução do horário de funcionamento (Hungria e Finlândia, dentre outros).

\footnotetext{
27 Para uma visão panorâmica analisando os principais impactos da pandemia do COVID-19 no que se refere ao acesso aos direitos e à justiça, no cenário internacional, com indicaçôes de diretrizes e recomendaçốes para superação dos desafios quer no que se refere às medidas imediatas quer com relação a perspectivas e providências futuras, recomenda-se consulta ao documento "Guidance Note: Ensuring Accesso to Justice in the Contexto of COVID-19”, elaborado pelo UNODC - United Nations Drugs and Crime e pelo UNDP - United Nations Development Programme. Disponível em: https://www.unodc.org/documents/AdvocacySection/Ensuring_Access_to_Justice_in_the_Context_of_COVID-191.pdf. Acesso em 31/01/2021.

28 Ver: http://globalaccesstojustice.com/impacts-of-covid-19/?lang=pt-br. Acesso em 31/01/2021.
} 
Embora essas medidas sejam, na maioria dos casos, efetivamente razoáveis e necessárias, a pesquisa revelou que em $31 \%$ dos países pesquisados foram registradas situaçóes que pareciam configurar injustificadas violaçóes de direitos humanos, cometidas sob o pretexto de se conter a propagaçáo do COVID-19. Esse tipo de relato se deu mesmo em países formalmente considerados sob regime democrático, que se pautam pelos princípios do Estado de Direito, como é o caso da Africa do Sul, onde foi apurado pela pesquisa uma ocorrência - que ainda estava sob investigaçáo - em que 8 (oito) pessoas teriam sido mortas, executadas por policiais ou autoridades militares, por suposta violação à quarentena imposta no país ${ }^{29}$.

Exatamente para que esses atos restritivos de direitos não deem margem a abusos e arbitrariedades, tem sido ressaltada a importância de se atentar para critérios de proporcionalidade, com limitação temporal de medidas de exceção, e vedação a discriminaçóes incompatíveis com a dignidade da pessoa humana, assegurada sempre a possibilidade de controle judicial de sua razoabilidade. Daí a importância de se zelar pelo regular funcionamento dos serviços jurisdicionais e, na perspectiva dos mais necessitados, dos serviços de assistência jurídica gratuita, como é o caso daqueles prestados pela Defensoria Pública ou por serviços equivalentes adotados nos diversos países.

Em certas situaçóes, o efetivo funcionamento de mecanismos adequados para viabilizar o acesso aos direitos e à justiça, especialmente para os mais vulneráveis pode ser indispensável mesmo para salvar vidas e preservar a integridade física das pessoas. Isso ocorre, por exemplo, na garantia de tratamento e assistência médico-hospitalar (especialmente em casos em que seja necessária vaga em UTI - unidade de terapia intensiva), na prevenção e contenção de casos de violência doméstica e de casos de tortura ou - especificamente neste contexto da pandemia - nas hipóteses em que a soltura de presos pode ajudar a evitar a disseminaçáo do vírus SARs-CoV-2 no sistema carcerário e no sistema correicional infanto-juvenil.

Tomando como referência a situação verificada na fase inicial da pandemia, conforme dados da pesquisa "Impactos do COVID-19 nos Sistemas de Justiça”, já acima referida, realizada no âmbito do Global Access to Justice Project, em $47 \%$ dos países participantes foi informado terem sido adotadas medidas destinadas à redução da população carcerária. Dentre tais medidas foram mencionadas: a soltura antecipada de presos antes do término de sua pena, a concessão de regime de prisão domiciliar e a flexibilização do regime semiaberto ou aberto com dispensa de retorno para pernoite no estabelecimento prisional. Dentre os critérios adotados para liberar pessoas (que se encontravam encarceradas) da permanência na prisão foram indicados os seguintes: quantitativo da pena, enquadramento em grupo de risco e, ainda, natureza do crime praticado.

Uma outra questáo preocupante que foi consideravelmente agravada no contexto da pandemia do COVID-19 foi a da violência doméstica contra a mulher. Em todo o mundo verificou-se a necessidade de adoção de medidas específicas para prevenir e conter crimes e atos de violência no lar, não apenas à mulher, mas também a crianças e adolescentes. Na pesquisa acima referida foram reportadas inúmeras açóes específicas implementadas por órgãos estatais dentre as quais

29 ESTEVES, Diogo; ALVES, Cleber Francisco; SILVA, Franklyn Roger Alves; Azevedo, Júlio Camargo. Acesso à Justiça em tempos de pandemia: o impacto global do COVID-19 nas instituiçóes político-jurídicas. Confluências - Revista Interdisciplinar de Sociologia e Direito. Niterói-RJ, Vol. 22, N. 2, ago/dez 2020, pp. 147-170. 
podemos mencionar: (i) campanhas de conscientização envolvendo o combate à violência de gênero (Espanha, França, Grécia, Portugal, Serra Leoa e Suíça); (ii) reforço do serviço de atendimento telefônico policial (Espanha, França e Grécia); (iii) criação de linhas específicas de denúncia (Argentina, Espanha, Portugal, Quênia e Uruguai); (iv) apoio psicológico por meio de Whats App (Espanha); (v) adoção de medidas imediatas para a evicção do agressor e manutenção da vítima no lar familiar (França); (vi) disponibilização de centros de proteção para acolhimento imediato das vítimas evitando sua exposição ao contágio (Espanha); (vii) abertura parcial de creches e escolas infantis para atender filhos de mulheres mantidas no trabalho (Cuba, Finlândia e Holanda); (viii) medidas específicas de prevenção em abrigos femininos (Chile e Finlândia); e (ix) isenção de multa por desrespeito ao lockdown para mulheres vítimas de violência doméstica (Espanha e Macedônia do Norte) ${ }^{30}$.

No que se refere especificamente ao Brasil, quanto aos serviços de acesso à justiça e de assistência jurídica gratuita, cabe registrar que no dia 17 de março de 2020 o Conselho Nacional de Justiça - CNJ - publicou a Recomendação no 62/2020 preconizando a adoção de medidas preventivas à propagação da infecção pelo novo coronavírus no âmbito dos estabelecimentos do sistema prisional e do sistema socioeducativo. Dentre tais medidas estavam: a aplicação preferencial de medidas socioeducativas a adolescentes em meio aberto; a revisão das decisôes que determinaram a internação provisória; a reavaliação de medidas socioeducativas de internação e semiliberdade, para fins de eventual substituição por medida em meio aberto, suspensão ou remissão; a reavaliação - pelos juízes com competência criminal - das prisóes provisórias, na forma do art. 316, do Código de Processo Penal, enfatizando-se a "máxima excepcionalidade" da decretação de novas prisóes provisórias; a suspensão do dever de apresentação periódica ao juízo das pessoas em liberdade provisória ou suspensão condicional do processo. Com relação às prisões civis, por dívidas de alimentos, foi expressamente recomendada a opção pela colocação em prisão domiciliar.

No dia 19 de março de 2020 o CNJ aprovou a Resolução no 313/2020 que instituiu o regime de Plantão Extraordinário no Judiciário brasileiro a ser cumprido de modo remoto, com a suspensão do expediente forense regular e, em consequência, do trabalho presencial de magistrados, servidores, estagiários e colaboradores nas unidades judiciárias. No art. $4^{\circ}$ dessa Resoluçáo foram elencados os $\operatorname{casos}^{31}$ que seriam obrigatoriamente apreciados nesse regime de Plantão, e no art. 5\% foi determinada a suspensão temporária dos prazos proces-

\footnotetext{
30 Idem. Ibidem.

31 Dentre esses casos, foram expressamente previstos: habeas corpus e mandado de segurança; medidas liminares e de antecipaçáo de tutela de qualquer natureza, inclusive no âmbito dos juizados especiais; comunicaçóes de prisão em flagrante, pedidos de concessão de liberdade provisória, imposição e substituição de medidas cautelares diversas da prisão, e desinternação; representação da autoridade policial ou do Ministério Público visando à decretação de prisão preventiva ou temporária; pedidos de busca e apreensão de pessoas, bens ou valores, interceptaçóes telefônicas e telemáticas, desde que objetivamente comprovada a urgência; pedidos de alvarás, pedidos de levantamento de importância em dinheiro ou valores, substituiçáo de garantias e liberação de bens apreendidos, pagamento de precatórios, Requisiçôes de Pequeno Valor - RPVs e expedição de guias de depósito; pedidos de acolhimento familiar e institucional, bem como de desacolhimento; pedidos de progressáo e regressão cautelar de regime prisional, concessão de livramento condicional, indulto e comutaçáo de penas e pedidos relacionados com as medidas previstas na Recomendação CNJ n 62/2020; pedidos de cremação de cadáver, exumação e inumação; e autorização de viagem de crianças e adolescentes, observado o disposto na Resolução CNJ n 295/2019. Posteriormente, pela Resolução no 317, de 30.4.2020, foram também incluídos processos relacionados a benefícios previdenciários por incapacidade e assistenciais de prestaçáo continuada.
} 
suais, tendo porém sido ressalvado que tal suspensão prevista não obstaria a prática de ato processual necessário à preservação de direitos e de natureza urgente, na forma do Art. $4^{\circ}$.

Importante destacar que em praticamente todos os tribunais brasileiros os processos judiciais já se encontravam, em sua maioria ou quase totalidade, digitalizados e tramitando regularmente em plataformas eletrônicas. De modo que, embora tenha sido determinada a suspensão dos prazos processuais e das atividades presenciais nos fóruns judiciais, isso não implicaria necessariamente na paralisação do trâmite processual, sendo que o art. $6^{\circ} \mathrm{da}$ supramencionada Resoluçáo 313/2020 do CNJ previa a possibilidade de regulamentaçáo do trabalho remoto de magistrados e servidores para dar andamento nos atos processuais que não dependessem de atividade presencial, inclusive a eventual realização de sessões de julgamento virtuais.

Em sintonia com os termos da Resolução 313/2020 do CNJ, considerando-se que inexiste no Brasil um órgáo de âmbito nacional, similar ao referido Conselho, que seja competente para definir normas padronizadas relativas ao funcionamento das Defensorias Públicas em todo o país, no exercício da autonomia administrativa assegurada por normas constitucionais e legais, as Defensorias Públicas Estaduais e a Defensoria Pública da União igualmente baixaram atos regulamentares suspendendo suas atividades presenciais. Foram definidos procedimentos e editadas normas para implantar e regulamentar a prestaçáo dos serviços de assistência jurídica gratuita por via remota. No âmbito da Defensoria Pública da União, por exemplo, foi editada a Portaria GABDPGF DPGU no 193, de 16 de março de 2020, depois alterada pela de número 205, de 19 de março, na qual foi dispensado o comparecimento, nos locais de funcionamento dos respectivos órgãos de atuação, dos defensores públicos, servidores e estagiários. Foi, então, autorizado, em caráter excepcional, o trabalho por meio remoto, estabelecendo-se que somente seriam realizados atendimentos (se necessários, presenciais) de casos considerados urgentes, assim definidos pela Resolução DPGU 103/2014. No caso da Defensoria Pública do Estado do Rio de Janeiro, já no dia 12 de março de 2020 foi publicada a Resoluçáo DPGERJ no 1.042/2020 e, logo depois, em 19 de março, a Resolução Conjunta 05/2020 (DPGE-Corregedoria), que estabeleceu um regime especial de trabalho com escala de rodízio para atendimento presencial em Pólos de Atendimento Remoto, sendo que aqueles defensores públicos, servidores e estagiários que não estivessem atuando na escala deveriam passar a atuar em regime de teletrabalho, por via remota. Disposiçóes similares foram adotadas por todas as demais Defensorias Públicas estaduais do Brasil.

Embora em grande medida, como indicado acima, os serviços forenses na maior parte dos tribunais do Brasil já estivessem amplamente informatizados, com a quase totalidade dos processos judiciais digitalizados, tramitando em formato eletrônico, muitos atos processuais por suas próprias características, como é o caso das audiências de instrução e julgamento ou - com ainda mais razão - das audiências de custódia e dos julgamentos pelo Tribunal do Júri, continuavam sendo ordinariamente realizados de forma presencial. Porém, com a suspensão de atividades presenciais decorrente da eclosão da pandemia, essas audiências presenciais foram inicialmente suspensas. Assim, para permitir a observância do princípio da continuidade da prestação jurisdicional (art. 93, XII, da Constituição Federal), o CNJ, através da Resolução no 329, de 30 de julho de 2020, definiu regras autorizando e regulamentando a realização das audiências judiciais e outros atos processuais, 
de modo remoto, por videoconferência ${ }^{32}$. De qualquer sorte, parece inequívoco que essa possibilidade/autorização para realização de audiências e sessôes de julgamento por videoconferência nos tribunais consiste em solução paliativa que não é capaz de substituir de modo pleno o encontro e contato presencial do(s) julgador com as partes, seus patronos e eventuais testemunhas. Daí que é necessário admitir que a suspensão das atividades presenciais devido à pandemia do COVID-19 apresenta vários impactos que são prejudiciais, de algum modo, os serviços de prestação jurisdicional.

No que se refere aos serviços prestados pelas Defensorias Públicas, é preciso ter presente que o estágio de informatização e digitalização de seus serviços ainda é bastante variado pelo país afora. Além disso, especialmente no que diz respeito à realização de atendimentos iniciais, para orientação e assessoramento sobre exercício e fruição de direitos, e para a propositura de novas demandas judiciais quando isto seja indispensável, a suspensão dos atendimentos presenciais ou a limitação ao atendimento apenas de casos graves e urgentes configura situação preocupante, já que muitas vezes implica, na prática, em retardamento ou, até mesmo, em denegação da possibilidade de acesso à justiça. Mesmo para dar conta do efetivo atendimento daqueles casos mais graves e urgentes, nesse período da pandemia do COVID-19, inúmeras tem sido as barreiras e dificuldades enfrentadas, tanto na perspectiva da própria instituição - Defensoria Pública - quanto dos destinatários de seus serviços. Os atendimentos realizados por via remota dependem em grande medida da disponibilizaçáo de recursos tecnológicos, e da respectiva capacidade/aptidáo para sua utilização, o que muito frequentemente não ocorre.

Não se pode desconsiderar que, nos últimos anos, verificou-se um grande esforço no sentido de melhor aparelhamento da infraestrutura das Defensorias Públicas no que se refere aos equipamentos e redes de informática, ao aprimoramento dos programas e sistemas de comunicação e de processamento de dados e à capacitação dos recursos humanos, inclusive dos defensores públicos, para melhor aproveitamento e utilização das novas tecnologias no desempenho de suas atividades ${ }^{33}$; porém, a situação ainda estava muito longe do desejável. Paralelamente, mesmo que essa não fosse a realidade e que o estágio

\footnotetext{
32 No que se refere especificamente às audiências de custódia, cuja realização - pela própria especificidade desse importante mecanismo de controle da legalidade das prisões pré-processuais - deveria ocorrer sempre presencialmente, o Art. 19 da Resolução no 329/2020, do CNJ, vedou expressamente sua realização por videoconferência. Mas, em 24/11/2020, o Conselho aprovou um Ato Normativo admitindo eventual realizaçáo de audiência de custódia por videoconferência, embora em caráter excepcional, no período de subsistência da pandemia do COVID-19.

33 Para exemplificar o que aqui se afirma podemos tomar como referência uma iniciativa da Defensoria Pública fluminense, em parceria com a Universidade Federal do Rio de Janeiro (Coppe-UFRJ), ou seja, o, assim denominado, Sistema Verde (para mais informações, ver detalhamentos no "manual do usuário" disponível em: https://verde.ri.def.br/verde/pages/pauta/pauta.xhtm), que começou a ser desenvolvido no ano de 2016, sendo que em 2020, diante dos desafios suscitados pela pandemia do COVID-19, foi lançado o aplicativo Defensoria RJ, disponibilizado gratuitamente aos cidadáos nas lojas virtuais de aplicativos. Para mais informaçôes sobre os potenciais impactos das novas tecnologias nos serviços da Defensoria Pública recomenda-se a leitura, dentre outros, dos seguintes trabalhos: SOUSA, José Augusto Garcia; PACHECO, Rodrigo Baptista. Os impactos da revoluçáo tecnológica sobre a Defensoria Pública: breve estudo à luz das "ondas" renovatórias da instituição. In: MAIA, Maurílio Casas (org). Defensoria Pública, Democracia e Processo II. São Paulo: Tirant Lo Blanch, 2021.
} 
de desenvolvimento tecnológico das Defensorias estivesse mais avançado, há que se ter presente que o público alvo prioritário da instituição consiste exatamente nas pessoas que enfrentam as maiores dificuldades para ter acesso às tecnologias e aos meios mais sofisticados de comunicação. São aqueles que se costuma designar de "excluídos digitais" ou "vulneráveis digitais" ou, ainda "vulneráveis tecnológicos" ${ }^{34}$, não apenas por força das limitaçóes sócio-econômico-financeiras, mas também pela insuficiência do nível educativo-instrucional ou pelas barreiras de índole generacional.

Assim, há que se reconhecer que embora meritórios os esforços feitos para assegurar, com a maior agilidade possível, a migração para o regime de atendimento remoto, com utilização de recursos tecnológicos, o que de certo modo evitou a total solução de continuidade na prestação dos serviços de assistência jurídica gratuita, parece inequívoco que a nova sistemática de atendimento não foi capaz de suprir as dificuldades de acesso aos serviços da Defensorias Pública que já eram enfrentadas pelas populaçóes mais vulneráveis no plano sócio-econômico e cultural, e que se agravaram ainda mais, notadamente no que se refere aos "excluídos digitais". Por esse motivo, muitas foram as vozes que se levantaram criticando as decisóes tomadas pela dirigentes da Defensoria Pública no início da pandemia, de suspensão total dos atendimentos presenciais. Dentre tais vozes, pode ser mencionada a fala da pesquisadora Gabriela Lotta, da FGV-SP, que em entrevista concedida à Agência Brasil assim se pronunciou a respeito da decisão de suspensão dos atendimentos presenciais na Defensoria quando da eclosão da Pandemia do COVID-19:

"[A Defensoria Pública] é um serviço que foi decidido que não se mantivesse face a face. Diferentemente de várias áreas de assistência, da própria saúde, em que os profissionais continuaram atuando na face-a-face com os cidadãos. O trabalho da Defensoria Pública é um trabalho que virou, em grande medida, homeoffice...Um trabalho que vira bomeoffice para uma populaçáo vulnerável significa deixar o ônus para essa populaçáo. Ao mesmo tempo que os profissionais estáo protegidos, náo estáo colocando a saúde deles em risco, isso gera um conjunto de ônus para a própria populaçáo que náo consegue ter acesso a um serviço virtualizado, digitalizado." ${ }^{35}$ (grifos nossos)

Essas críticas se basearam exatamente no entendimento de que a assistência jurídica gratuita tem caráter de serviço público de natureza essencial, tal como a saúde e a segurança pública, cuja prestaçáo não pode ocorrer apenas "à distância”, por via remota, como de fato se deu em muitos órgãos da Defensoria Pública, principalmente na fase inicial da pandemia. Com efeito, parece inequívoco que os serviços de acesso à justiça - não só o regular funcionamento dos órgãos jurisdicionais, mas também das funçóes consideradas essenciais à Justiça, como é o caso da Defensoria Pública - devem ser reconhecidos, como indicado na própria expressáo do texto constitucional, como

${ }^{34}$ GONÇALVES FILHO, Edilson Santana. Acesso à Justiça é impactado pela vulnerabilidade digital. In: ConJur - Revista Eletrônica Consultor Jurídico. Disponível em: https://www.conjur.com.br/2020-jun-23/ tribuna-defensoria-acesso-justica-impactado-vulnerabilidade-digital. Acesso em 30/01/2021.

35 Entrevista disponível em: https://agenciabrasil.ebc.com.br/justica/noticia/2020-08/pandemia-afastouvulneraveis-do-acesso-justica-revela-pesquisa, publicada em 04/08/2020. Acesso em 10/02/2021. 
serviços essenciais. Por isso, consideramos corretas essas críticas relativamente a medidas que determinaram a suspensáo total das atividades presenciais, tanto nos Fóruns judiciais quanto nas Defensorias Públicas. $\mathrm{O}$ argumento de que era necessário proteger a saúde e até a vida dos profissionais das carreiras jurídicas e auxiliares não nos parece suficiente para justificar tais medidas. A exposiçáo ao risco é um ônus inerente à opção

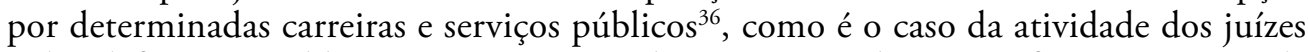
e dos defensores públicos. Do mesmo modo que um médico ou enfermeiro não pode se recusar trabalhar num hospital sob o argumento de que teme ser contaminado por alguma doença, ou que um policial náo pode ser recusar a realizar uma atividade de patrulhamento sob o argumento de que teme ser vítima de um ataque de um criminoso, também os defensores públicos não poderiam recusar-se a permanecer "na linha de frente" do atendimento presencial, muitas vezes indispensável aos destinatários de seus serviços, sob a justificativa de que precisavam proteger a sua saúde ou segurança. $\mathrm{O}$ que parece plausível seria apenas que se garantisse a disponibilidade de equipamentos básicos de proteção sanitária, conforme protocolos de segurança sanitária cientificamente recomendados e definidos pelas autoridades públicas competentes. E, munidos desses equipamentos, permanecer na "linha de frente", mantendo abertas as unidades da Defensoria Pública para atendimento dos destinatários que fazem jus ao serviço estatal essencial de assistência jurídica integral e gratuita.

Então, como bem destacado pela Prof. Gabriela Lotta, na sua fala acima transcrita, parece-nos que a suspensáo total de atendimentos presenciais pelas Defensorias Públicas (e no Judiciário!), na prática, representaria "denegação do acesso à justiça”, na medida em que inviabiliza quase que totalmente a possibilidade - especialmente para os mais vulneráveis econômica e socialmente - de obter medidas indispensáveis para assegurar a efetividade de seus direitos, seja por meio da prestação jurisdicional, quando necessária, ou de outros mecanismos adequados para resguardo e efetividade de seus direitos fundamentais. A "substituiçáo" dos serviços e atividades presenciais por atividades remotas, pode eventualmente até ser adequada e conveniente desde que se mantenha em funcionamento - ainda que em sistema de plantão - o atendimento presencial para situaçóes de excepcionalidade. Destarte, parece-nos indispensável ter especial atenção e adotar providências efetivas destinadas a garantir o atendimento presencial daqueles que náo disponham de acessibilidade a equipamentos e tecnologias suficientemente eficazes de comunicação à distância, assim como à observância de procedimentos necessários ao cumprimento dos parâmetros formais e substanciais inerentes ao devido processo legal, assegurado o contraditório e ampla defesa.

De qualquer sorte, embora no que se refere ao atendimento de casos de natureza individual a adoçáo do modelo de atendimento remoto e a implantação do regime de teletrabalho tenha suscitado críticas e controvérsias, o fato é que na perspectiva transindividual e na busca de mecanismos de cunho preventivo, não só judicialmente mas

\footnotetext{
36 Para um estudo mais amplo sobre essa questão do importante papel que deve ser desempenhado por certas carreiras e serviços públicos que atuam na "linha de frente", diretamente junto aos cidadãos, recomenda-se fortemente a leitura da importante obra "Burocracia em nível de rua: dilemas do indivíduo nos serviços públicos", do Prof. Michael Lipsky. Para download gratuito da versão em português, publicada em 2019: https://repositorio.enap.gov.br/bitstream/1/4158/1/Burocracia\%20de\%20n\%c3\%advel\%20de\%20rua_ Michael\%20Lipsky.pdf Acesso em 12/02/2021.
} 
também extrajudicialmente, cabe reconhecer que as Defensorias Públicas brasileiras tem realizado um notável trabalho, desde o início da pandemia do COVID-19. Isso é o que se pode constatar, por exemplo, das iniciativas descritas em trabalho elaborado pelos defensores públicos Edilson Santana Gonçalves Filho, Jorge Bheron Rocha e Maurílio Casas Maia, sob o título "Defensoria Pública e Acesso à Justiça na Pandemia do Coronavirus". Esse trabalho foi publicado como capítulo do livro "Coronavírus Direitos dos Cidadáos e Acesso à Justiça”, organizado por Fernanda Tartuce e Luciano Souto Dias, no ano de 2020.

Nesse trabalho ${ }^{37}$, os autores enumeram o ajuizamento de várias açóes de Habeas Corpus coletivos, ${ }^{38}$ no Superior Tribunal de Justiça, por defensores públicos além de outras providências administrativas junto ao $\mathrm{CNJ}$, pugnando por medidas de tutela de direitos de pessoas privadas da liberdade, com o objetivo de contribuir para evitar a proliferaçáo da pandemia no ambiente carcerário. Na seara cível, foram elencadas atuaçóes coletivas diversas destinadas à reivindicação de direitos e proteção dos interesses de vários grupos de pessoas em situação de vulnerabilidade. Segundo dados levantados pelos autores junto à Assessoria de Comunicação da Defensoria Pública da União, foram ajuizadas açóes coletivas, dentre outras, relativas a temas como: a necessidade de fornecimento de Equipamentos de Proteção Individual (EPIs) aos profissionais de saúde atuantes no SUS, incremento das equipes médicas e expansão dos leitos de UTI; a disponibilização de leitos e reforço da estrutura hospitalar para atendimento da população, em especial a que se compóe de etnias indígenas; o acolhimento de pessoas em situaçáo de rua em equipamentos públicos, assim como a adoção de políticas públicas específicas para este público durante a pandemia e seu acesso ao auxílio emergencial, etc. Outrossim, em todo o país, foram ajuizadas açóes, enviadas recomendaçôes, expedidos ofícios e adotadas medidas variadas - como por exemplo - com o propósito de que a Caixa Econômica Federal tomasse providências para reduzir as filas e aglomeraçóes em frente às agências em razáo do pa-

37 GONÇALVES FILHO, Edilson; ROCHA, Jorge Bheron; MAIA, Maurílio Casas. Defensoria Pública e Acesso à Justiça na Pandemia do Coronavírus. In: TARTUCE, Fernanda; DIAS, Luciano Souto (coord). Coronavírus - Direitos dos Cidadáos e Acesso à Justiça. Indaiatuba,SP: Editora Foco, 2020.

38 De se notar que, formalmente, não existe previsão na legislação brasileira prevendo a figura do Habeas Corpus coletivo, embora na doutrina se sustente a tese pela sua admissibilidade (Ver: ROCHA, Jorge Bheron. Habeas Corpus coletivo: uma proposta de superaçáo do prisma individualista. In: ConJur Revista Eletrônica Consultor Jurídico. Disponível em: https://www.conjur.com.br/2017-mai-30/ tribuna-defensoria-hc-coletivo-proposta-superacao-prisma-individualista). Porém, no contexto da pandemia do COVID-19, várias Defensorias Públicas pelo país afora impetraram açóes de Habeas Corpus coletivo, buscando obter a liberação do cárcere em favor de de pessoas privadas da liberdade, com o propósito de resguardar sua saúde e vida, e evitar a disseminação do coronoavirus no ambiente prisional. Dentre o público alvo para o pretendido benefício pode-se mencionar presos por dívida de alimentos, pessoas encarceradas que sejam pais ou responsáveis pelos cuidados de crianças menores de 12 anos ou com deficiência, presos idosos ou integrantes do grupo de risco da Covid-19 no país, que praticaram crimes sem violência e estivessem detidos em estabelecimentos superlotados. Apesar disso, porém, nem sempre essas postulações tiveram boa receptividade no Judiciário, como analisado no trabalho de Carolina Costa Ferreira. (FERREIRA, Carolina Costa. Encarceramento em Massa e Pandemia: limites das respostas processuais coletivas. In: MELO, Ezilda; BORGES, Lize; SERAU JUNIOR, Marco Aurélio. Covid-19 e o Direito Brasileiro - mudanças e impactos. Sáo Paulo: Tirant lo Blanch, 2021. Disponível para download gratuito em: https://editorial.tirant. com/free_ebooks/9786586093971.pdf. Acesso em 15/02/2021.) 
gamento do benefício do auxílio emergencial, assim como para facilitar o acesso aos que dele necessitam. Foram também relatadas por esses autores medidas destinadas à tutela de direitos de migrantes, com relação aos quais as principais atuaçóes coletivas teriam se dado no sentido de garantir direitos previstos na Constituição Federal, como acesso ao sistema de saúde e a benefícios assistenciais. Houve, ainda, recomendaçóes e - quando necessário - ajuizamento de ação pugnando pela distribuição de alimentos adquiridos para a merenda escolar diretamente para os pais ou responsáveis pelos estudantes durante o período da pandemia do coronavírus. Na maioria das Defensorias Públicas Estaduais também foram ajuizadas açóes coletivas sobre assuntos correlatos, cabendo destacar atuaçóes extrajudiciais no âmbito dos Parlamentos Estaduais com sugestão de projetos de leis diversos voltados para proteção dos interesses e direitos do público alvo dos serviços da instituição em razão dos efeitos da pandemia do COVID-19 $9^{39}$.

\section{REFLEXÓES SOBRE OS EFEITOS DA PANDEMIA DO COVID-19 NO PRE- SENTE E NO FUTURO DA ATUAÇÃO DA DEFENSORIA PÚBLICA}

Antes mesmo da eclosão da pandemia do COVID-19, já se verificava em muitos países a crescente utilização de recursos tecnológicos para facilitar e agilizar os serviços públicos e privados relacionados ao acesso à justiça e à assistência jurídica. Essa realidade também já se fazia presente no Brasil. No âmbito do Judiciário, na última década verificou-se uma ampla expansão da "informatização judicial", que foi alavancada pela aprovação da Lei 11.419/2006, conhecida como "Lei do Processo Eletrônico" ${ }^{40}$.

Esse processo de informatização e de incorporação de recursos tecnológicos e comunicacionais, embora não tenha se verificado ainda de forma táo ampla e profunda como ocorrido no Judiciário, já vinha também avançando no âmbito das Defensorias Públicas $^{41}$, conforme destacado por Franklyn Roger Alves Silva, em artigo publicado no ano de 2019:

\footnotetext{
39 A título de exemplo, ver: https://www.conjur.com.br/2020-mar-18/alerj-aprova-lei-coibe-corte-servicosaumento-precos; https://www.defensoria.ce.def.br/noticia/sancionada-a-lei-que-proibe-aumento-de-precosdurante-a-pandemia-proposta-foi-sugerida-pela-defensoria/; e https:/www.defensoria.ba.def.br/noticias/ coronavirus-proposta-de-projeto-de-lei-que-protege-consumidores-e-apresentada-a-assembleia-legislativapela-defensoria/ Acesso em 12/02/2021.

40 Para um estudo mais sistemático acerca da informatização judicial no Brasil e acerca do processo judicial eletrônico recomenda-se o livro "Processo Eletrônico e Teoria Geral do Processo Eletrônico - a informatizaçáo judicial no Brasil" de autoria do saudoso professor petropolitano José Carlos de Araújo Almeida Filho (meu colega de graduaçáo na UCP e colega de magistério na UFF), cuja 3a edição foi publicada em 2010 pela Editora Forense do Rio de Janeiro.

41 Conforme já mencionado em nota anterior, para uma visão geral sobre os impactos da revolução tecnológica sobre a Defensoria Pública, e suas potencialidades, recomenda-se a leitura de artigo recém-publicado, de autoria de José Augusto Garcia de Sousa e Rodrigo Baptista Pacheco, cujo título é "Os impactos da revoluçáo tecnológica sobre a Defensoria Pública: breve estudo à luz das "ondas" renovatórias da instituição". Cabe ainda indicar o livro "Defensoria Pública e o Futuro: accountability, Matriz Swot, IA e os Robôs", de autora de José Roberto Oliveira de Paula Machado.
} 
"Várias Defensorias Públicas estaduais e a própria Defensoria Pública da União têm se utilizado da tecnologia da informação como forma de potencializar a prestaçáo da assistência jurídica e facilitar o acesso de seus usuários. Desde uma maior interação em redes sociais com o exercício de um papel de educaçáo em direitos; o uso de plataformas de comunicaçáo digital (WhatsApp, Facebook e e-mail) para minorar as dificuldades da comunicaçáo por carta e acelerar a transmissão da informação; o uso de sistemas de gerenciamento de informaçôes para construção de bancos de dados no âmbito da instituição; além do uso de centrais telefônicas e outros canais para dúvidas, tudo feito como forma de ampliar o acesso aos serviços institucionais." ${ }^{42}$

Todavia, como bem destacado pelo mesmo autor, devido a inúmeras deficiências de infraestrutura por ele apontadas e, agregamos nós, pela existência de profundas limitaçóes orçamentárias e financeiras das próprias Defensorias além de enormes dificuldades enfrentadas pelos cidadáos destinatários dos seus serviços para acesso a equipamentos e recursos tecnológicos adequados, o cenário não era muito promissor para o futuro próximo: ao invés de facilitar o acesso à justiça a tecnologia da informação poderia configurar um verdadeiro obstáculo. Entretanto, como já visto, com a eclosão da pandemia do COVID-19 e adoção do regime de trabalho remoto imposto pela necessidade de isolamento e distanciamento social, entendeu-se que não havia alternativa capaz de assegurar a continuidade dos serviços de assistência jurídica gratuita a cargo das Defensorias Públicas senão "ativando e intensificando o uso de canais virtuais, como, por exemplo, comunicação por aplicativos de mensagens instantâneas, formulários digitais, e-mail, chatbot, ligaçóes telefônicas, videoconferências etc.” 43

Parece, então, inequívoco que a pandemia do COVID-19 teve dentre seus efeitos positivos o de acelerar sobremaneira o aprimoramento e inovação no emprego de recursos tecnológicos e comunicacionais na prestação da assistência jurídica gratuita, a cargo da Defensoria Pública. Dentre os exemplos pode ser mencionado o lançamento, em outubro de 2020, do aplicativo Defensoria RJ, disponibilizado gratuitamente aos cidadãos nas lojas virtuais de aplicativos. Esse aplicativo - que é parte do "Sistema Facilitador $V E R D E$ ", software criado por técnicos da COPPE/UFRJ, cuja finalidade é oferecer à Defensoria ferramentas de informática capazes de integrar rotinas e procedimentos facilitadores das atividades e serviços prestados pela instituição, conforme já acima mencionado neste trabalho - tem se revelado uma importante ferramenta tecnológica, na medida em que facilita a interaçáo entre os usuários e a Defensoria permitindo realizar agendamento de atendimentos remotos e presenciais; encaminhamento de documentaçóes; consulta, remarcação e cancelamento de agendamentos; além de acompanha-

42 SILVA, Franklyn Roger Alves. Tecnologia da informação como recurso ou obstáculo ao acesso à Justiça. In: ConJur - Revista Eletrônica Consultor Jurídico. Disponível em https://www.conjur.com.br/2019-mai-07/ tribuna-defensoria-tecnologia-informacao-recurso-ou-barreira-acesso-justica. Acesso em 12/02/2021.

43 GONÇALVES FILHO, Edilson Santana; LEITÃO, Raíssa Vianna; SOARES, Vitor Valdir Ramalho. Defensoria Pública e o paradoxo criado pelas novas formas de atendimento: adaptação institucional aos novos paradigmas tecnológicos e promoção da inclusão digital. In: ConJur - Revista Eletrônica Consultor Jurídico. Disponível em https://www.conjur.com.br/2021-fev-09/tribuna-defensoria-paradoxo-criado-pelasnovas-formas-atendimento. Acesso em 12/02/2021. 
mento e informações sobre processos, intimaçóes e ações ajuizadas. Vislumbra-se para o futuro muitas outras possibilidades ${ }^{44}$ como desdobramento e aprimoramento do Sistema Facilitador Verde, agregando-se o uso de mecanismos de inteligência artificial, a implementação de plataformas interativas (na linha dos sistemas de on line dispute resolution) que - em questóes menos complexas - possam até mesmo permitir ao próprio usuário que gere/obtenha documentos/requerimentos eventualmente necessários para o exercício de seus direitos e que consigam resolver de modo autônomo eventuais problemas mais simples do cotidiano.

De qualquer sorte, como destacado no tópico anterior, também é preciso reconhecer que foram gigantescas as dificuldades encontradas para se viabilizar a migração dos serviços e atendimentos prestados pela Defensoria Pública do modelo presencial para o modelo à distância, por via remota, em decorrência da pandemia do COVID-19. E, conforme tem sido constatado, esse novo formato tem causado impactos tanto de cunho positivo quanto negativo na efetividade dos serviços. Trata-se de um paradoxo que foi objeto de análise em recente artigo publicado na "Tribuna da Defensoria Pública" - coluna semanal da Revista eletrônica Conjur, que trata de questóes relacionadas à atividade defensorial ${ }^{45}$. Como bem salientado no texto em tela, "um dos maiores desafios da Instituição no contexto do uso de novas tecnologias estará relacionado à exclusão tecnológica/digital, tendo em vista que esta faz emergir mais uma barreira a ser enfrentada tanto pela pessoa assistida quanto pelas defensoras e defensores públicos: a vulnerabilidade digital”. E, prosseguindo nessa análise, os autores do artigo argumentam que "as novas tecnologias apresentam um paradoxo: ao tempo em que podem potencializar o acesso à justiça, também são capazes de criar obstáculos, afetando a capacidade pessoal de acessá-la.” Assim, em que pese a necessidade de se atentar para as limitaçóes e barreiras que surgem nesse cenário, não se pode também deixar de reconhecer as virtudes e benefícios ${ }^{46}$ que o uso da tecnologia pode

\footnotetext{
44 As potencialidades e utilidades do Sistema Verde não se restringem à facilitação da atividade "fim" da Defensoria Pública, mas também à sistematizaçáo de dados de grande importância no aspecto organizacional e gerencial da instituição. Assim, cabe citar o Verde em Dados, uma ferramenta de business intelligence que permite a geração de relatórios a partir dos dados disponibilizados na plataforma. Tais relatórios sáo exibidos em painéis de controle informativos, que podem ser modificados para cruzar informaçóes através de filtros. Essa ferramenta é uma forma de valorizar a transparência da instituição, facilitando o acesso a dados estatísticos atualizados, inclusive com visualização através de gráficos, que permitem maior transparências às atividades realizadas pelos órgãos da Defensoria. Para maior detalhamento, ver: https://defensoria.rj.def.br/ Institucional/verde-em-dados. Acesso em 13/02/2021.

45 Idem. Ibidem.

46 No mesmo artigo cuja referência completa está na nota 43 supra, os autores elencam vários exemplos positivos de situaçôes em que a utilização dos recursos tecnológicos, com a possibilidade de atuação de forma remota, pode potencializar a máxima efetividade do direito à assistência jurídica: permite a prática de atos processuais urgentes a qualquer momento e de qualquer local, sem perda de tempo com deslocamento física, inclusive diminuindo o tempo de resposta. Isso pode representar maior quantidade de "tempo líquido" de dedicação à atividade institucional, suprimindo o tempo desperdiçado - especialmente em razáo do tráfego congestionado de veículos nas grandes cidades - com o deslocamento até as sedes operacionais da instituição ou aos locais de realizaçáo de audiências e reunióes.
} 
propiciar. Esse será, certamente, um bom legado que poderá ficar, após o fim da pandemia do COVID-19 $9^{47}$.

Assim, tomando como base ainda os dados apontados no trabalho acima referido, pelo país afora foram registrados números expressivos e, de certo modo, surpreendentes, no que se refere ao quantitativo de atos processuais e de atendimentos realizados à distância, nos períodos em que os serviços presenciais ficaram praticamente suspensos devido às determinaçōes de isolamento social para contenção da COVID-19. Em muitos casos, conforme tem sido relatado por defensores públicos de todo o país, nota-se que muitas pessoas que eram destinatárias dos serviços de assistência jurídica gratuita mas que normalmente por circunstâncias diversas acabavam não tendo acesso à Defensoria Pública passaram a fazê-lo. Com efeito, no modelo "tradicional" de atendimento presencial, que era predominante até então (ou, na maioria das vezes, era o modelo exclusivo adotado), a necessidade de deslocamento por longos percursos (sobretudo para pessoas que residem em locais remotos, da zona rural, em municípios de vasta extensão) entre a residência do usuário e o local de atendimento implicava em dispêndio de tempo (além de gastos com transporte!) que nem sempre era disponível, especialmente porque normalmente o horário de funcionamento das Defensorias coincidia com o horário de trabalho dos usuários. A possibilidade de atendimento por telefone, por correspondência eletrônica (email), ou - sobretudo - pelo táo disseminado aplicativo Whatsapp $p^{48}$ tem facilitado sobremaneira a acessibilidade de um número considerável de pessoas que possuem acesso relativamente fácil às tecnologias da informação e comunicação e que, antes, talvez não conseguissem utilizar os serviços da Defensoria Pública devido a barreiras burocráticas e operacionais do modelo muitas vezes anacrônico entáo adotado, muitas vezes concebido à luz das perspectivas e conveniências dos prestadores dos serviços e não dos seus destinatários ${ }^{49}$.

\footnotetext{
47 Para uma reflexão acerca dessa correlação entre a pandemia do COVID-19 e seu impacto no que se refere ao uso das tecnologias no campo do acesso à justiça, recomendamos a leitura do artigo de autoria do Prof. Roger Smith, um dos mais qualificados especialistas mundiais nessa temática, que corresponde a transcrição de palestra por ele proferida no II Seminário de Tecnologia e Defensoria, no dia 14 de outubro de 2020, promovido pela Defensoria Pública do Rio de Janeiro. (SMITH, Roger. COVID-19, Tecnologia e Acesso à Justiça. Tradução: Cleber Francisco Alves e Anna Carolina Mendes da Silva. In: Revista de Direito da Defensoria Pública do Rio de Janeiro. Ano 29, No 30, 2020.)

${ }_{48}$ Dentre várias iniciativas que poderiam ser aqui mencionadas, na dificuldade de completo levantamento das criativas e inovadoras experiências positivas verificadas no contexto da pandemia, citamos um projeto levado a efeito no interior da Bahia, em que o Centro de Mediaçáo e Conciliaçáo da Defensoria Pública da cidade de Vitória da Conquista, naquele Estado, logrou êxito em obter solução extrajudicial consensual, de modo remoto, utilizando-se da ferramenta Whatsapp Business, num expressivo número de casos. Ver: https://www.defensoria.ba.def.br/noticias/coronavirus-com-trabalho-remoto-defensoria-firmou-75-dosacordos-de-mediacao-por-aplicativo-de-mensagem-em-vitoria-da-conquista/ Acesso em 12/02/2021.

49 Para um aprofundamento sobre essa delicada e complexa questão acerca da priorização dos interesses dos clientes em contraste com os interesses da estrutura burocrática nos modelos organizacionais dos serviços públicos, sugerese consulta às interessantes reflexōes do autor Michael Lipsky, no seu livro "Burocracia em nível de rua: dilemas do indivíduo nos serviços públicos", já referido em nota de rodapé anterior. Igualmente, para uma visão específica do serviço defensorial, devem ser lembradas as oportunas e pertinentes reflexóes e propostas que constam das obras de autoria do defensor público Adolfo Filgueiras Etienne: "Defensoria Pública: excelência no atendimento e nas postulaçóes judiciais", publicada em 2018 pela Editora CEI, de Belo Horizonte, e "Defensoria Pública e Gestão", cuja 2a edição foi publicada em 2019 pela Editora Lumen Juris, do Rio de Janeiro.
} 
Tudo indica que - passada a pandemia - não se retornará ao velho (e, como nos parece agora, em muitas situaçóes, obsoleto) "normal” no funcionamento dos serviços da Defensoria Pública. A probabilidade é que teremos uma versão híbrida na prestação dos serviços de assistência jurídica gratuita no pós COVID-19, empregando-se aqui uma expressão usada pelo defensor público José Alberto Oliveira de Paula Machado ${ }^{50}$. De acordo com esse autor,

\begin{abstract}
"a pandemia nos faz rememorar que a Defensoria Pública deve ser sempre a instituiçáo das reinvençôes. Urge a criação de um novo ecossistema de acesso à Justiça e prestação de serviço tanto para aqueles que estão em vulnerabilidade tecnológica quanto para a maioria que já usufrui das TICs (tecnologias da informação e comunicação). Um serviço público que reflita a dignidade das individualidades deve ser sempre o "normal".
\end{abstract}

De qualquer sorte, é importante ressaltar que a adoção desse modelo híbrido se justifica pelo fato de que muitos dos usuários da Defensoria Pública, sobretudo aqueles que não possuem ou não conseguem utilizar os recursos tecnológicos e comunicacionais, continuarão necessitando do atendimento presencial. Inclusive, parte considerável dos destinatários da Defensoria Pública somente será alcançada se adotada uma postura proativa, utilizando-se procedimentos de "busca ativa" (ou outreach, para usar a consagrada expressão em idioma inglês ${ }^{51}$ ), em que o defensor público precisa sair de seu Gabinete para ir ao encontro dos cidadãos hipervulnerabilizados que muitas vezes sequer tem consciência de que tem direitos a serem reivindicados e efetivados, como ocorre por exemplo com a população em situação de rua.

Uma última consideração que deve ser feita quanto a possível efeito nefasto decorrente da pandemia do COVID-19 relativamente ao serviço de assistência jurídica gratuita prestado pela Defensoria Pública decorre da provável situação de crise de índole orçamentário-financeira que deverá ser enfrentada nos próximos anos. A redução das receitas públicas e o aumento das despesas para fazer face ao enfrentamento da pandemia vão agravar a situação do déficit fiscal, tornando muito mais difícil o cumprimento das determinaçóes emanadas da Emenda Constitucional 80/2014, que determinava o prazo de 08 (oito) anos, ou seja, até, 2022, para a implantação de órgãos da Defensoria Pública em todas as unidades territoriais jurisdicionais onde a instituição ainda não está presente. $\mathrm{O}$ cumprimento da Emenda Constitucional depende necessariamente da ampliação - não apenas em termos absolutos mas também proporcionais - das verbas orçamentárias atribuídas

\footnotetext{
${ }^{50}$ MACHADO, José Alberto Oliveira de Paula. Seja bem-vinda a versão híbrida da Defensoria Pública pós-Covid-19. In: ConJur - Revista Eletrônica Consultor Jurídico. Disponível em: https://www.conjur. com.br/2020-jul-21/tribuna-defensoria-seja-bem-vinda-versao-hibrida-defensoria-publica-pos-covid-19. Acesso em 12/02/2021.

51 Para uma reflexão inicial a respeito da importância de iniciativas de "busca ativa", tão pouco debatidas e difundidas no meio jurídico brasileiro, especialmente pelas Defensorias Públicas onde isso precisaria ser mais estudado, recomenda-se a leitura do artigo Outreach legal services to people with complex needs: what works?, de autoria de Suzie Forell e Abigail Gray. In: Justice Issues, (12), October/2009. Disponível para download em: http://www.lawfoundation.net.au/ljf/site/articleIDs/69EBF819BDD1BB8BCA25766A0082208C/\$file/ JI12_Complex_Needs_web.pdf. Acesso em 10/12/2020.
} 
pelos Poderes Legislativos (Federal e Estaduais) às Defensorias Públicas, o que é necessário para viabilização de medidas e projetos destinados à expansão de sua cobertura territorial e do alcance da prestaçáo de serviços para maiores parcelas do público alvo que legalmente e constitucionalmente deveriam ter direito à assistência jurídica integral e gratuita a ser prestada pelo poder público.

Mas isso não é totalmente impossível: depende de vontade política e da consciência de que - no contexto intra e pós-pandemia - deveriam ser reconhecidas como ainda mais prioritárias as ações e políticas públicas estatais voltadas para a proteção dos interesses dos mais frágeis. Com efeito, "não podemos deixar ninguém para trás" 52 , consoante expressamente afirmado pelo segundo "princípio universal" estabelecido na Agenda 2030 para o Desenvolvimento Sustentável proposta pela Organização das Naçóes Unidas... Um exemplo animador nesse sentido, que pode aqui ser mencionado, é o da Defensoria Pública do Estado do Rio de Janeiro, unidade federativa que notoriamente enfrenta um dramático quadro de austeridade orçamentária e financeira, com reiterados déficits fiscais nos últimos anos. Apesar desse cenário desfavorável, de modo contínuo e progressivo, ao longo dos últimos anos, tem se obtido êxito em reverter um quadro lamentável que havia se verificado no passado recente de decréscimo (proporcionalmente às demais funçóes essenciais e entidades autônomas) do orçamento da Defensoria Pública.

Nos últimos 5 (cinco) anos, o Poder Legislativo Fluminense, em sintonia com o Poder Executivo, por proposta da Administração Superior da Defensoria Pública, vem aprovando uma progressiva "recomposição" orçamentária da DPGE-RJ, assegurando-lhe fatias percentuais sucessivamente crescentes em comparação com o que é destinado aos demais Poderes e entidades estatais autônomas equivalentes ${ }^{53}$. Isso tem permitido não só a manutenção dos serviços da assistência jurídica mas até mesmo um certo aprimoramento e melhoria nas condiçóes de seu funcionamento e a implementação de novos projetos de atuação, o que resulta em inequívoco benefício para os destinatários do serviço. Esse processo de recuperação orçamentária - mesmo em tempos de austeridade - traduz uma vontade política de índole suprapartidária, em que os Deputados Estaduais e o Governador do Estado tem reconhecido a importância do serviço prestado pela Defensoria Pública. Para o ano de 2021, por exemplo, a Lei Orçamentária Anual do Estado do Rio de Janeiro autorizou um aumento de quase $40 \%$ na dotação orçamentária relativa ao "custeio" (em que, deve ser ressaltado, náo se incluem as despesas com remuneraçáo de pessoal) dos serviços da Defensoria Pública, o que se traduz num fato notável, de grande importância diante dos desafios a serem enfrentados em decorrência da pandemia da COVID-19. Essas con-

\footnotetext{
52 "Leave no one behind (LNOB) is the central, transformative promise of the 2030 Agenda for Sustainable Development and its Sustainable Development Goals (SDGs). It represents the unequivocal commitment of all UN Member States to eradicate poverty in all its forms, end discrimination and exclusion, and reduce the inequalities and vulnerabilities that leave people behind and undermine the potential of individuals and of humanity as a whole." Ver: https://unsdg.un.org/2030-agenda/universal-values/leave-no-one-behind. Acesso em 08/02/2021.

$53 \mathrm{O}$ detalhamento dessa trajetória de fortalecimento e recuperação orçamentária pode ser verificando no "Portal da Transparência", da DPGE-RJ, onde constam todos os dados institucionais, cabendo destacar que já no primeiro ano da sequência acima mencionada (de 2015 para 2016) o orçamento da Defensoria foi aprovado com um aumento de 16\% em comparação com o ano anterior. Ver: https://transparencia.rj.def.br/ execucao-orcamentaria/index. Acesso em 16/02/2021.
} 
quistas somente estão sendo alcançadas graças à habilidade das lideranças da Defensoria Pública, seja pela credibilidade dos integrantes da sua Administração Superior, e também dos dirigentes da entidade de representação classista, assim como pelo reconhecimento da seriedade e importância dos próprios serviços prestados pelos integrantes da instituição na "linha de frente", junto aos cidadãos, nos diversos bairros e Municípios do Estado.

\section{CONSIDERAÇÓES FINAIS}

Ao término destas reflexóes sobre o impacto da pandemia de COVID-19 no acesso aos direitos e à justiça, especialmente quanto a seus efeitos no presente e no futuro da Defensoria Pública, não podemos ignorar o quadro mais amplo, na perspectiva nacional e mundial, que se descortina sombrio e preocupante para o futuro próximo, de modo ainda mais grave para os estratos menos favorecidos da sociedade local e global. Mesmo com a esperança da rápida descoberta de imunizantes que inclusive já estão sendo aplicados em diversos países, embora num ritmo ainda preocupantemente lento em nosso país, parece inequívoco que o legado dessa pandemia será bastante penoso para toda a humanidade e em particular para o Brasil. Mas, por outro lado, não podemos deixar de reconhecer que - paradoxalmente - poderemos sim colher alguns legados positivos.

Assim, tão logo superada a fase da crise mais aguda, caberá certamente uma reflexão e avaliação sobre as respostas efetivamente adotadas e as medidas implementadas para proteger e promover o acesso das pessoas aos direitos e à justiça, no contexto da pandemia. É desejável que nesse processo de reflexão se busque identificar e compartilhar boas práticas entre os diversos atores e instituiçóes nessa seara, não apenas quanto aos serviços públicos, mas também as iniciativas do setor privado e da sociedade civil.

Nesse sentido, o uso de tecnologias remotas para atendimentos dos usuários e para a prática de atos judiciais, o desenvolvimento de sistemas informatizados facilitadores dos serviços de assistência jurídica, dentre outros esforços, podem e devem ser continuados no período pós-pandemia e têm potencial para um impacto duradouro e de longo alcance.

Estratégias e práticas inovadoras de sucesso adotadas durante a crise devem ser fomentadas e aprimoradas. Aperfeiçoar as boas práticas experimentadas nesse período particularmente desafiador e assegurar meios para permitir seu uso continuado pode ajudar a superar algumas das barreiras sistêmicas que as pessoas enfrentam no acesso aos direitos e à justiça. O estímulo à inovação tem suscitado oportunidades de reformulaçóes e investimentos em novas maneiras de tornar o serviço de assistência jurídica mais acessível e "responsivo" às necessidades dos usuários.

É bem provável que o regime de teletrabalho seja mantido em significativa proporção nos diversos serviços e atividades em que sua eficácia tenha se revelado como positiva, rompendo-se um certo preconceito que ainda existia, no sentido de que essa modalidade de atuação seria menos produtiva do que a presencial. Isso implicará certamente na adoção de modelos híbridos de funcionamento de órgáos públicos - como por exemplo nos Tribunais e órgãos judiciários em geral, inclusive nas Defensorias Públicas - o que pode facilitar a atuação dos diversos profissionais e servidores, evitando deslocamento e perda 
de tempo como ocorre, por exemplo em casos de realização de sustentação oral em sessóes de julgamento, quando muitas vezes o profissional tem que permanecer a tarde inteira à disposição, enquanto que se feita remotamente, pode continuar "trabalhando" no escritório e interromper apenas no momento exato em que tenha que falar; essa possibilidade pode ser vantajosa em vários aspectos, com otimização de tempo, superaçáo de barreiras geográficas, redução de custos, etc. Do mesmo modo, semelhantes vantagens e benefícios poderão ser auferidos pelos próprios destinatários dos respectivos serviços.

Para concluir, cabe enfatizar que a pandemia do COVID-19 tem levado também a uma reflexão sobre a importância do papel proativo e intervencionista do Estado, numa linha de ação mais sintonizada com o modelo do keynesianismo, cabendo-lhe promover açóes e medidas concretas para proteção dos mais frágeis. Tem sido resgatada a consciência da importância do fomento à solidariedade social em detrimento de visóes individualistas e privatistas. Assim, na área propriamente dita da Saúde, resta evidente que a pandemia demonstrou como é importante a existência de um sistema público estatal forte e abrangente - como é o caso do SUS brasileiro que, apesar dos pesares, muitos "pesares" - corrupção, postura errática e equivocada da esfera federal no desempenho de suas funçóes - evitou um possível de quadro ainda mais caótico e dramático que poderia ter se verificado.

Também na seara do acesso à justiça e, sobretudo da assistência jurídica gratuita, o modelo estatal de Defensoria Pública adotado pelo Brasil, a despeito de possíveis deficiências, tem se revelado capaz de assegurar - não apenas no aspecto da tutela dos interesses individuais mas, sobretudo, de iniciativas e estratégias coletivas, com monitoramento e fiscalização de políticas públicas respectivas - a continuidade dos serviços necessários para promover o acesso aos direitos e à Justiça por parte dos destinatários de seus serviços. Isso certamente seria mais difícil de se alcançar caso o modelo adotado fosse o de advogados particulares atuando de modo avulso e sem uma articulaçáo e infraestrutura organizacional e institucional para lhes dar o necessário suporte para esse desempenho. Assim, a despeito do cenário de restrições orçamentário-financeiras, é de grande importância fortalecimento e aprimoramento de serviços públicos estatais como o prestado pela Defensoria Pública brasileira.

\section{REFERÊNCIAS}

ALMeIDA FILHO, José Carlos de Araújo. Processo Eletrônico e Teoria Geral do Processo Eletrônico - a informatizaçáo judicial no Brasil. 3a ed. Rio de Janeiro: GEN/Forense, 2010.

ALVES, Cleber Francisco. Justiça para todos! A assistência jurídica gratuita nos Estados Unidos, na França e no Brasil. Rio de Janeiro: Lumen Juris, 2006.

ALVES, Cleber Francisco; GONZÁLEZ, Pedro. Defensoria Pública no Século XXI - Novos Horizontes e Desafios. 2a ed. Rio de Janeiro: Lumen Juris, 2019.

CRUZ, Paulo Márcio. Da Soberania à Transnacionalidade: Democracia, Direito e Estado no Século XXI. Itajaí: UNIVALI, 2014. 
CRUZ, Paulo Márcio; BODNAR, Zenildo. Globalizaçáo, Transnacionalidade e Sustentabilidade. Itajai: UNIVALI, 2012.

ESTEVES, Diogo; ALVES, Cleber Francisco; SILVA, Franklyn Roger Alves; Azevedo, Júlio Camargo. Acesso à Justiça em tempos de pandemia: o impacto global do COVID-19 nas instituiçóes político-jurídicas. Confluências - Revista Interdisciplinar de Sociologia e Direito. Niterói-RJ, Vol. 22, N. 2, ago/dez 2020.

ETIENNE, Adolfo Filgueiras. Defensoria Pública e Gestáo. 2a ed. Rio de Janeiro: Lumen Juris, 2019.

ETIENNE, Adolfo Filgueiras. Defensoria Pública: excelência no atendimento e nas postulaçóes judiciais. Belo Horizonte: Editora CEI, 2018.

FERRARI, Andrés Ferrari; CUNHA, André Moreira. A pandemia de Covid-19 e o isolamento social: saúde versus economia. Disponível em: https://www.ufrgs.br/coronavirus/base/artigo-apandemia-de-covid-19-e-o-isolamento-social-saude-versus-economia/ Acesso em 09/02/2021.

FERREIRA, Carolina Costa. Encarceramento em Massa e Pandemia: limites das respostas processuais coletivas. In: MELO, Ezilda; BORGES, Lize; SERAU JUNIOR, Marco Aurélio. Covid-19 e o Direito Brasileiro - mudanças e impactos. São Paulo: Tirant lo Blanch, 2020. Disponível para download gratuito em: https://editorial.tirant.com/free_ebooks/9786586093971. pdf. Acesso em 15/02/2021.

FORELL, Suzie \& GRAY, Abigail. Outreach legal services to people with complex needs: what works? In: Justice Issues, (12), October/2009. Disponível para download em: http://www. lawfoundation.net.au/ljf/site/articleIDs/69EBF819BDD1BB8BCA25766A0082208C/\$file/ JI12_Complex_Needs_web.pdf. Acesso em 10/12/2020.

GARCIA, Marcos Leite. Direitos Fundamentais e Transnacionalidade: um estudo preliminar. In: CRUZ, Paulo Márcio; STELZER, Joana (orgs.). Direito e Transnacioinalidade. Curitiba: Juruá, 2009.

GONÇALVES FILHO, Edilson Santana. Acesso à Justiça é impactado pela vulnerabilidade digital. In: ConJur - Revista Eletrônica Consultor Jurídico. Disponível em: https://www.conjur. com.br/2020-jun-23/tribuna-defensoria-acesso-justica-impactado-vulnerabilidade-digital. Acesso em $30 / 01 / 2021$.

GONÇALVES FILHO, Edilson Santana; LEITÃO, Raíssa Vianna; SOARES, Vitor Valdir Ramalho. Defensoria Pública e o paradoxo criado pelas novas formas de atendimento: adaptação institucional aos novos paradigmas tecnológicos e promoção da inclusão digital. In: ConJur - Revista Eletrônica Consultor Jurídico. Disponível em https://www.conjur. com.br/2021-fev-09/tribuna-defensoria-paradoxo-criado-pelas-novas-formas-atendimento. Acesso em 12/02/2021.

GONÇALVES FILHO, Edilson; ROCHA, Jorge Bheron; MAIA, Maurílio Casas. Defensoria Pública e Acesso à Justiça na Pandemia do Coronavírus. In: TARTUCE, Fernanda; DIAS, Luciano Souto (coord). Coronavírus - Direitos dos Cidadáos e Acesso à Justiça. Indaiatuba,SP: Editora Foco, 2020.

GREER, Scott L.; KING, Elizabeth J.; PERALTA-SANTOS, André; FONSCA, Elize Massard (ed.). Coronavirus Politics - The Comparative Politics and Policy of COVID-19. Michigan: University of Michigan Press, 2021. 
HABERMAS, Jurgen . Màs allá del Estado Nacional. Traducción y introducción de Manuel Jiménez Redondo. 4ed. Madrid: Trota, 2008.

KLOH, Fabiana Ferreira Pimentel; ALVES, Cleber Francisco. Conselho Tutelar diz que aulas presenciais violam direitos das crianças: o relativismo na obrigatoriedade da frequência à escola e a opçáo pela educação domiciliar. In: VASCONCELOS, Maria Celi Chaves (org). Educaçáo Domiciliar no Brasil: mo(vi)mento em debate. Curitiba: Editora CRV, 2021.

LIPSKY, Michael. Burocracia em nível de rua: dilemas do indivíduo nos serviços públicos. Brasília: Escola Nacional de Administração Pública (Enap), 2019. Disponível para download em: https://repositorio.enap.gov.br/bitstream/1/4158/1/Burocracia\%20de\%20n\%c3\%advel\%20 de\%20rua_Michael\%20Lipsky.pdf. Acesso em 15/02/2021.

LYRA, Aline; SOARES, Antônio Jorge Gonçalves. Reflexóes acerca da Educação Domiciliar e da Desescolarizaçáo a partir do cenário de pandemia In: VASCONCELOS, Maria Celi Chaves (org). Educaçáo Domiciliar no Brasil: mo(vi)mento em debate. Curitiba: Editora CRV, 2021.

MACHADO, José Alberto Oliveira de Paula. Defensoria Pública e o Futuro: accountability, Matriz Swot, IA e os Robôs. São Paulo: Tirant Lo Blanch, 2019.

MACHADO, José Alberto Oliveira de Paula. Seja bem-vinda a versão híbrida da Defensoria Pública pós-Covid-19. In: ConJur - Revista Eletrônica Consultor Jurídico. Disponível em: https://www.conjur.com.br/2020-jul-21/tribuna-defensoria-seja-bem-vinda-versao-hibridadefensoria-publica-pos-covid-19. Acesso em 12/02/2021.

MARRAFON, Marco Aurélio. CF estabelece cooperação federativa para superar crise do coronavírus. In: ConJur - Revista Eletrônica Consultor Jurídico. Disponível em: https:// www.conjur.com.br/2020-mar-30/constituicao-poder-cf-estabelece-cooperacao-federativa-crisecovid-19. Acesso em 10/02/2021.

MELO, Ezilda; BORGES, Lize; SERAU JUNIOR, Marco Aurélio. Covid-19 e o Direito Brasileiro - mudanças e impactos. São Paulo: Tirant lo Blanch, 2020. Disponível para download gratuito em: https://editorial.tirant.com/free_ebooks/9786586093971.pdf. Acesso em 15/02/2021.

ROCHA, Jorge Bheron. Habeas Corpus coletivo: uma proposta de superação do prisma individualista. In: ConJur - Revista Eletrônica Consultor Jurídico. Disponível em: https:// www.conjur.com.br/2017-mai-30/tribuna-defensoria-hc-coletivo-proposta-superacao-prismaindividualista. Acesso em 20/02/2021.

SILVA, Franklyn Roger Alves. Tecnologia da informação como recurso ou obstáculo ao acesso à Justiça. In: ConJur - Revista Eletrônica Consultor Jurídico. Disponível em https://www.conjur. com.br/2019-mai-07/tribuna-defensoria-tecnologia-informacao-recurso-ou-barreira-acessojustica. Acesso em 12/02/2021.

SMITH, Roger. COVID-19, Tecnologia e Acesso à Justiça. Tradução: Cleber Francisco Alves e Anna Carolina Mendes da Silva. In: Revista de Direito da Defensoria Pública do Rio de Janeiro. Ano 29, No 30, 2020.

SOUSA, José Augusto Garcia; PACHECO, Rodrigo Baptista. Os impactos da revolução tecnológica sobre a Defensoria Pública: breve estudo à luz das “ondas” renovatórias da instituição. 
In: MAIA, Maurílio Casas (org). Defensoria Pública, Democracia e Processo II. São Paulo: Tirant Lo Blanch, 2021.

STRAPAZZON, Carlos Luiz. Respostas à pandemia e a estratégia brasileira. In: Revista Eletrônica do Centro Universitário Newton Paiva. Belo Horizonte, n. 41, mai/ago 2020.

UJVARI, Stefan Cunha. Pandemias: a humanidade em risco. São Paulo: Contexto, 2011.

UNODC - United Nations Drugs and Crime; UNDP - United Nations Development Programme. Guidance Note: Ensuring Accesso to Justice in the Contexto of COVID-19. Disponível em: https://www.unodc.org/documents/Advocacy-Section/Ensuring_Access_to_Justice_in_the_ Context_of_COVID-191.pdf. Acesso em 31/01/2021. 